\title{
Assessment of user embracement with risk rating in emergency hospital services
}

\author{
Avaliação do acolhimento com classificação \\ de risco em serviços de emergência hospitalar \\ Evaluación de acogimiento con clasificación de riesgo \\ en los servicios de emergencia hospitalaria
}

\author{
Gelena Lucinéia Gomes da Silva Versa ${ }^{a}$ \\ Dagmar Wilamowius Vituri ${ }^{b}$ \\ Aline Aparecida Buriolac \\ Carlos Aparecido de Oliveirad $^{d}$ \\ Laura Misue Matsuda
}

DOl: $\quad$ http://dx.doi.org/10.1590/1983-

1447.2014.03.45475

\section{ABSTRACT}

Cross-sectional and quantitative study, conducted in 2013, aiming to evaluate the implementation of User Embracement with Risk Rating (ACCR) in four Emergency Hospital Services. One hundred fifty six nurses participated and answered the questionnaire "User Embracement with Risk Rating". The data were treated through descriptive and inferential statistics, from the Kruskal-Wallis test. The implementation of ACCR was assessed as precarious, mainly due to the lack of referral of low complexity cases to the basic health system, the inadequate physical space for companions and the lack of discussion and periodic assessment of the flow of care in ACCR. The dimension Result of Implementation obtained a slightly higher score and Structure was the dimension with the lowest score. It was concluded that the negative assessments by nursing professionals of the referred dimensions in the investigated sites suggests the need for improvements, especially in the dimension Structure.

Descriptors: Rating. User embracement. Emergency nursing.

\section{RESUMO}

Estudo transversal, quantitativo, realizado em 2013, com o objetivo de avaliar a implantação do Acolhimento com Classificação de Risco (ACCR) em quatro Serviços Hospitalares de Emergência. Participaram 156 profissionais de enfermagem, os quais responderam ao questionário Instrumento para Avaliação do Acolhimento com Classificação de Risco. Os dados foram tratados por meio de estatística descritiva e inferencial, a partir do teste Kruskal-Wallis. A implantação do ACCR foi avaliada como Precária, devido, principalmente, à falta de encaminhamento dos casos de baixa complexidade à rede básica de saúde, ao espaço físico inadequado para acompanhantes e à falta de discussão/avaliação periódica sobre 0 fluxo de atendimento no ACCR. A dimensão Resultado da implantação obteve avaliação um pouco melhor e a Estrutura foi a dimensão que obteve a maior pontuação. Concluiu-se que, nos locais investigados, a avaliação negativa dos profissionais sugere que há necessidade de se investir em melhorias, com destaque para a dimensão Processo. Descritores: Classificação. Acolhimento. Enfermagem em emergência.

\section{RESUMEN}

Estudio transversal, cuantitativo, realizado en 2013, con el objetivo de evaluar la implantación del Acogimiento con Clasificación de Riesgo (ACCR) en cuatro servicios hospitalarios de emergencia. Participaron 156 profesionales de enfermería, que respondieron al cuestionario de instrumento para el Acogimiento con Clasificación de Riesgo. Los datos fueron analizados utilizando estadística descriptiva e inferencial de la prueba de Kruskal-Wallis. La aplicación de la ACCR fue evaluada como precaria, debido principalmente a la falta de remisión de los casos de baja complejidad en el sistema básico de salud; al espacio físico inadecuado de compañeros y, a la falta de discusión y revisión periódica del flujo de servicio en ACCR. La dimensión Resultado de la implantación obtuvo evaluación mediana y; la Estructura obtuvo la puntuación más baja. Se concluyó que en los sitios investigados, hubo una evaluación negativa por los profesionales, lo que sugiere la necesidad de invertir en mejoras, destacando dimensión Estructura.

Descriptores: Clasificación. Acogimiento. Enfermería de urgencia. 


\section{口INTRODUCTION}

The Emergency Hospital Service (EHS) is aimed to assist people with severely impaired health and refer non-complexity patients to primary care services ${ }^{(1)}$. Thus, the basic assumption of EHS is the guarantee of access of people with more complex, urgent health care needs, in an organized way, in order to prevent iatrogenic complications caused by incorrect handling or treatments, preventing death or physical disability, either temporary or permanent ${ }^{(2)}$.

Despite the advances in the effective implementation of emergency units, they still present deficiencies, particularly regarding their inadequate resources to deal with overcrowding due to the rapidly increasing demand for healthcare services ${ }^{(3)}$. And in an attempt to restructure the work process in this environment, as well as to reinforce the guidelines established by the $\mathrm{Na}$ tional Program for Humanization of Hospital Care(4), User Embracement with Risk Rating (ACCR) was proposed in 2004, within the scope of the National Policy of Humanization $(\mathrm{PNH})^{(4)}$.

The ACCR is based on international concepts established by the Manchester care protocol to replace the biomedical model according to which patients are seen in order of arrival, and not in order of urgency ${ }^{(5)}$. Under this new approach, the patients that arrive at the emergency health services are assisted according to clinical criteria, a dynamic health process that prioritizes care according to patient's potential risk and/or extent of injuries, in order to ensure higher quality care in emergency services ${ }^{(5)}$.

The implementation of the ACCR is aimed to reduce overcrowding and mortality rates in the EHS, by reducing the waiting time, based on risk rating of patients, integration of the healthcare network and referral of non-complexity patients to primary care units ${ }^{(6-7)}$. Therefore, ACCR is a strategy aimed to increase organizational efficiency through the restructuring of the healthcare system in Brazil ${ }^{(3,7)}$.

Regarding the implementation of $A C C R$, the nursing staff may act as the central coordinator of this new dynamics of care in the institution, because through risk rating management the nursing staff may increase their activities of support to comprehensive and compassionate care, enhancing the idea of comprehensive care and improving access to health care for users ${ }^{(3,7)}$.

However, the consolidation of ACCR in the EHS remains a challenge, since it does not depend entirely on the wishes of nurses, managers and/or users, but rather on the rearrangement of the different structural elements, human resources and on the healthcare process established by health care institutions ${ }^{(8-9)}$.

In view of the aforementioned, it is necessary to identify the gaps in the effective implementation of ACCR in EHS, and then discuss the adoption of measures aimed to improve compliance with the National Policy of Humanization (PNH). Thus, it is recommended that assessment tools especially designed and validated for the referred purpose are used, such as the one proposed by Bellucci Júnior and Matsuda ${ }^{(10)}$ based on Donabedian's dimensions.

The dimensions of assessment of quality in health care proposed by Donabedian include the Structure of health services, which assesses the asoects related to human, physical and material resources, equipment and financial aspects required by healthcare; the Process, which assesses the mode of work of the professionals; and Result, which concerns the health status of the patient seen in the healthcare service ${ }^{(11)}$. So, studies related to the quality of EHS are compelling because they may support improvements in these locations and facilitate decision making regarding the implementation of $A C C R$, regarding the provision of high-quality care.

Therefore, the following question can be asked: How do health professionals perceive the quality of EHS after the implementation of ACCR? In order to answer this question, the present study aimed to assess the implementation of User Embracement with Risk Rating (ACCR) in four Emergency Hospital Services of Paraná.

\section{METHODOLOGY}

Prospective, multicenter, exploratory study with a quantitative approach conducted from March to May, 2013, in four Emergency Hospital Services (EHS), randomly designed as I, II, III and IV.

The EHS I and II belong to charitable, non-profit hospitals located in the city of Maringá-PR, which provides care to private patients, operators of private healthcare schemes and Brazil's Unified Health Care System (SUS), with respectively 225 and 200 beds.

The EHS III and IV integrate general public hospitals of the state of Paraná, located in the city of Londrina, which provide $100 \%$ of beds to the SUS, with medium complexity care. Regarding the operational capacity, the EHS III has 117 beds, and, of these, 63 are intended for emergency and urgent care. As for EHS IV, it counts on 130 beds, of which, 34 beds are intended for emergency and urgent care. 
Regarding the implementation of ACCR: in EHS I, it occurred in 2011; in EHS II, in 2010; in EHS III, in 2009 and in EHS IV, in 2007.

The inclusion criteria adopted in this study were: being a nursing professional directly involved in the EHS for a minimum period of 01 (one) month.

Sampling was random, stratified and used proportional allocation of the nursing technicians/assistants and nurses of every assessed service.

For data collection, the professionals were chosen at random (draw) from a previous list of names. Then, the selected professionals were contacted in their workplaces and invited to participate in the study. After formal consent was obtained from participants, in a private room, the researchers provided the necessary instructions and handed out to participants the data collection instrument (questionnaire) for completion.

The study included 156 nursing professionals, as follows: 19 (12.2\%) from EHS I; 28 (19.9\%) from EHS II; 38 (24.4\%) from EHS III and 71 (45.5\%) from EHS IV.

The data collection instrument used in the research was the questionnaire "Instrumento para Avaliação do ACCR" (Instrument for Assessment of ACCR), which was designed and validated by Belluci in 2010, by means of content validation, using the Delphi technique that consists in the assessment of content validity by experts on the theme $e^{(10)}$. The referred instrument is composed of two parts: Part I, which includes items related to sociodemographic data from the subjects and Part II, which contains items specific for the collection of data related to ACCR assessment.

It should be stressed that Part II is subdivided into the Donabedian triad of Structure, Process and Result for use in health care assessment. The responses to these items are stated in the format of a five-level Likert scale: Completely Agree (1 point); Disagree (2 points); Neither Agree Nor Disagree (3 points); Agree (4 points) and Completely Agree (5 points) ${ }^{(10)}$

Chart 1 contains the general description of the 21 variables that compose each dimension of the instrument ${ }^{(10)}$.

The data were compiled and treated in electronic worksheets of Microsoft Office Excel and later imported to the Statistica 8.0 software. Descriptive statistical analysis of the results of Part I was conducted. In Part II (ACCR assessment) the type of scoring of each item, dimension assessment and inferential statistics were checked with median test (Kruskal-Wallis test).

The assessment of each dimension of Part II of the instrument was based on the classification ${ }^{(10)}$ contained in Table 1, as follows.

The present research complied with all ethical and legal requirements ${ }^{(12)}$ and the project is registered at the Standing Committee on the Ethics of Research involving Human Participants (COPEP) of Universidade Estadual de Maringá, under no. 248.339/2013.

\begin{tabular}{|l|l|l|}
\multicolumn{2}{|c|}{ Structure } & Process \\
\hline $\begin{array}{l}\text { 1. The physical structure promotes } \\
\text { comfort to the user }\end{array}$ & $\begin{array}{l}\text { 8. Health care that makes the user feel } \\
\text { safe / comfortable }\end{array}$ & 15. Patients seen in order of urgency \\
\hline $\begin{array}{l}\text { 2. ACCR makes the health care } \\
\text { environment warmer and more } \\
\text { compassionate }\end{array}$ & $\begin{array}{l}\text { 9. Low-complexity patients are not } \\
\text { submitted to ACCR }\end{array}$ & 16. Information on the waiting time \\
\hline 3. There are periodical trainings & $\begin{array}{l}\text { 10. ACCR conducts are known by } \\
\text { everyone }\end{array}$ & $\begin{array}{l}\text { 17. Professionals are received by } \\
\text { leaders }\end{array}$ \\
\hline $\begin{array}{l}\text { 4. The physical space provides privacy } \\
\text { to users }\end{array}$ & $\begin{array}{l}\text { 11. Leaders democratically discuss } \\
\text { changes }\end{array}$ & $\begin{array}{l}\text { 18. Health care integrated to the } \\
\text { needs }\end{array}$ \\
\hline $\begin{array}{l}\text { 5. The physical space provides } \\
\text { comfort to patients' companions }\end{array}$ & $\begin{array}{l}\text { 12. ACCR flowchart is periodically } \\
\text { discussed/assessed }\end{array}$ & $\begin{array}{l}\text { 19. Care prioritized according to the } \\
\text { severity of patient's condition }\end{array}$ \\
\hline $\begin{array}{l}\text { 6. The notice boards used in the } \\
\text { facilities are clearly understood by } \\
\text { users }\end{array}$ & $\begin{array}{l}\text { 13. Compassionate and resolutive } \\
\text { health care }\end{array}$ & $\begin{array}{l}\text { 20. Referral of low-complexity patients } \\
\text { to primary care }\end{array}$ \\
\hline $\begin{array}{l}\text { 7. Workers communicate with each } \\
\text { other frequently }\end{array}$ & $\begin{array}{l}\text { 14. Users waiting for care are } \\
\text { reassessed }\end{array}$ & 21. Humanization of health care \\
\hline
\end{tabular}

Chart 1 - General description of the variables of each dimension of the Instrument for the Assessment of ACCR ${ }^{(10)}$. 
Versa GLGS, Vituri DW, Buriola AA, Oliveira CA, Matsuda LM

Table 1 - Scores for the dimensions of ACCR assessment. Maringá-PR, 2014(10).

\begin{tabular}{cccc} 
Average score & Class Interval & Percentage (scores) & Assessment of Dimension \\
$31.5-35$ & 3.5 & $90-100$ & Excellent \\
$26.2-31.4$ & 5.4 & $75-89.9$ & Satisfactory \\
$17.5-26.1$ & 8.6 & $50-74.9$ & Precarious \\
$7-17.4$ & 10.4 & $0-49.9$ & Insufficient \\
\hline
\end{tabular}

Table 2 - Sociodemographic characteristics of nursing professionals who work in EHS. Maringá-PR, Londrina-PR, 2014.

\begin{tabular}{|c|c|c|c|c|c|}
\hline \multirow[b]{2}{*}{ Characteristics } & \multicolumn{5}{|c|}{ Institution } \\
\hline & $\begin{array}{c}H 1 \\
n=19\end{array}$ & $\begin{array}{c}\mathrm{H} 2 \\
n=28\end{array}$ & $\begin{array}{c}H 3 \\
n=38\end{array}$ & $\begin{array}{c}H 4 \\
n=71\end{array}$ & $\begin{array}{c}\text { General } \\
n=156\end{array}$ \\
\hline Average age (SD*) & $30,7(4,9)$ & $29,3(7,0)$ & $37,3(8,0)$ & $36,9(8,8)$ & $34,9(8,5)$ \\
\hline \multicolumn{6}{|l|}{ Gender (\%) } \\
\hline Male & $07(36,8 \%)$ & $09(32,1 \%)$ & $10(26,3 \%)$ & $22(31,0 \%)$ & $48(30,8 \%)$ \\
\hline Female & $12(63,2 \%)$ & $19(67,9 \%)$ & $28(73,7 \%)$ & $49(69,0 \%)$ & $108(69,2 \%)$ \\
\hline \multicolumn{6}{|l|}{ Marital status (\%) } \\
\hline Single & $09(47,4 \%)$ & $16(59,3 \%)$ & $10(27 \%)$ & $30(42,3 \%)$ & $65(41,7 \%)$ \\
\hline Married/Living with a partner & $08(42,1 \%)$ & $09(33,3 \%)$ & $19(51,4 \%)$ & $34(47,9 \%)$ & $70(44,9 \%)$ \\
\hline Widowed & 0 & $01(03,7 \%)$ & 0 & 0 & $01(00,6 \%)$ \\
\hline Separated/Divorced & $02(10,5 \%)$ & $01(03,7 \%)$ & $08(21,6 \%)$ & $07(09,9 \%)$ & $18(11,6 \%)$ \\
\hline \multicolumn{6}{|l|}{ Education (\%) } \\
\hline Elementary & 0 & 0 & 0 & $01(1,4 \%)$ & $01(00,6 \%)$ \\
\hline Complete secondary education & $11(57,9 \%)$ & $09(32,1 \%)$ & $29(76,3 \%)$ & $38(53,5 \%)$ & $87(55,8 \%)$ \\
\hline Complete Higher Education & $05(26,3 \%)$ & $06(21,4 \%)$ & $04(10,5 \%)$ & $11(15,5 \%)$ & $26(16,7 \%)$ \\
\hline Specialization & $03(15,8 \%)$ & $12(42,9 \%)$ & $05(13,2 \%)$ & $20(28,2 \%)$ & $40(25,6 \%)$ \\
\hline Masters & 0 & $01(03,6 \%)$ & 0 & $01(01,4 \%)$ & $02(01,3 \%)$ \\
\hline \multicolumn{6}{|l|}{ Professional Category } \\
\hline Nurse & $04(21,1 \%)$ & $18(64,3 \%)$ & $07(18,4 \%)$ & $20(28,2 \%)$ & $49(31,4 \%)$ \\
\hline Nursing Technician & $15(78,9 \%)$ & $10(35,7 \%)$ & $31(81,6 \%)$ & $49(69 \%)$ & $105(67,3 \%)$ \\
\hline Nursing Assistant & 0 & 0 & 0 & $2(2,8)$ & $02(01,3 \%)$ \\
\hline
\end{tabular}

\section{RESULTS}

Table 2 shows some sociodemographic characteristics of the participants.

Regarding the assessment of EHS after the implementation of ACCR, the general score of the dimensions assessed are shown in Table 3.
Chart 1, below, shows the distribution of the average score of the assessment of workers (vertical line) regarding the 21 items of the instrument (horizontal line).

\section{DISCUSSION}

As demonstrated in Table 2, most professionals that perform their duties at EHS are women (69.2\%), married 
Table 3 - Scores of assessment of ACCR, by dimension. Maringá-PR, Londrina-PR, 2014.

\begin{tabular}{lccc}
\multicolumn{1}{c}{ Dimensions } & Average Score & SD* & Assessment of Dimension \\
Structure & 23 points & 4.37 & Precarious \\
Process & 24 points & 3.58 & Precarious \\
Result & 26 points & 3.81 & Precarious \\
\hline
\end{tabular}

Source: Research data

(*) Standard Deviation

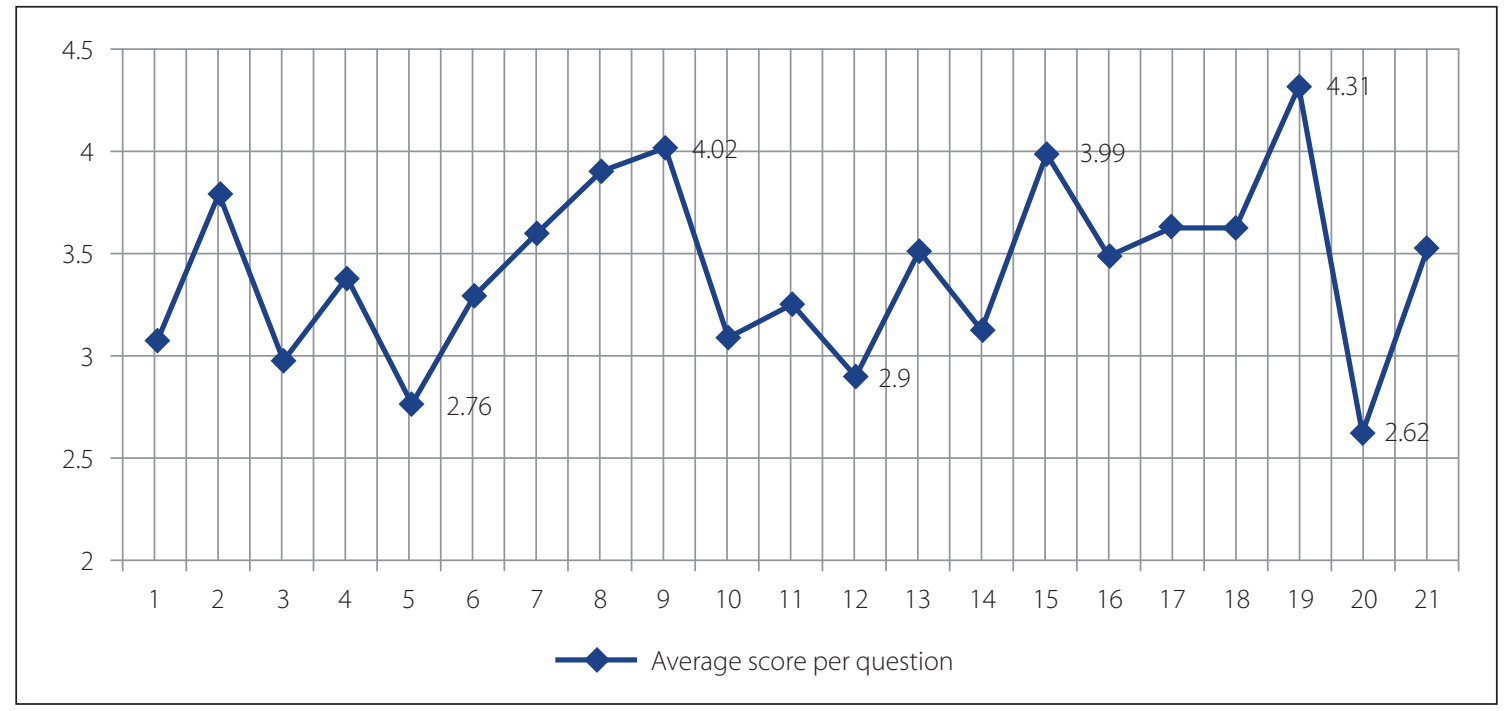

Chart 1 - Distribution of the average score (vertical) on the assessment of ACCR by assessed item (horizontal). Maringá-PR, Londrina-PR, 2014.

(44.9\%), young (average of 34.9 years), with secondary education (55.8\%) and their professional category is Nursing Technician (67.3\%).

Regarding gender, the vast majority of women among nursing professionals, it corroborates the history of the nursing profession, marked by the presence of women and their inclusion in the labor market ${ }^{(13)}$. The average age of 35 years of the participants in the study is consistent with the workplace, since relatively young professionals are more fit to cope with the stresses of heavy workload common in critical care and emergency units ${ }^{(13-14)}$.

According to another study conducted in Brazilian emergency care units, these workplaces tend to have younger, less experienced and untrained professionals ${ }^{(14)}$. The data obtained in the present study partly corroborate the above considerations, since we reported a higher prevalence of professionals with complete secondary education, minimum requirement for the position of nursing technician (67.3\%) in the assessed institutions.

Regarding the assessment of the quality of the services provided by emergency hospitals, as shown in Table 3 , the dimension Result obtained the highest score (26 points) and Structure, the worst (23 points). Concerning the quality scores, all emergency hospitals were classified as precarious.

The assessment of EHS quality as precarious may be related to the current situation of Brazilian healthcare institutions, often characterized by overcrowding, inadequate physical structure, lack of human resources and heavy workload ${ }^{(2)}$, corroborating the low scores obtained in this study for the following items: lack of referral of low-complexity cases to primary care services; insufficient physical space for patients' companions and lack of discussion/periodical assessment of the ACCR flow (Chart 1). 
Lack of and non-compliance with protocols of referral of low-complexity patients are a major impediment to the success of ACCR, since the disagreement between the several levels of health care results in increased demand in the EHS and long waiting periods and harm for patients who could be assisted by the primary care system ${ }^{(14)}$.

Improvement in the referral and counter-referral systems between hospitals and primary care services is urgent. However, this process is still under adaptation and improvement, for it is a relatively recent strategy, created in 1990 by the Brazilian Ministry of Health (MS), as an operational guideline of the National Policy for Humanization $(\mathrm{PNH})^{(15-16)}$.

An example of the above considerations, a study conducted in Rio Grande do Sul, in 2005, with the purpose of learning about the labor conditions of professionals who perform their duties emergency care, reported that the EHS investigated was an entry point for patients because, despite the advances in the reorganization of the health care model, the primary health care network was not able to meet the needs of the population ${ }^{(16)}$.

It is worth stressing that indiscriminate access of patients to the EHS significantly increases demand and, thus, the physical structure cannot provide appropriate care to users and their companions ${ }^{(15-17)}$. This was also observed in the present study, with the item "Physical space provides comfort to patients' companions" obtaining the second worst result (Chart 1, item 05).

The physical structure of the EHS should provide adequate conditions for patients and their companions, for this is one of the essential requirements proposed by the $\mathrm{PNH}^{(15-17)}$. Thus, the result "Precarious" observed in this study involves the need to confer dignity to the physical space.

Regarding the third worst result of this study, the item "The ACCR flowchart is discussed/periodically assessed", of the dimension Process (Chart 1, item 12), failure to undertake these activities impacts the entire ACCR process. Corroborating this statement, the authors ${ }^{(17)}$ indicate that health care teams that perform improvements and promote periodical discussions on the ACCR flowchart achieve better quality standards in the management of care.

Concerning the most positive assessments made by the professionals, the item "Care prioritized according to the severity of patient's condition" (Chart 1, item 19), of the dimension Result, obtained the highest score. This finding indicates that the main purpose of ACCR has been achieved. Also, regarding pre-hospital assessment of patients that arrive at the investigated EHS, our findings showed that the traditional system of patients seen in order of arrival has been replaced by a system that prioritizes urgency.

The second ranked item "Low-complexity patients are not submitted to ACCR" (Chart 1, item 9) concerns the dimension Process. This data demonstrates the commitment of health professionals to comply with $\mathrm{PNH}$, which proposes embracement of all users that seek health care services $^{(4)}$. Thus, it is worth stressing that despite the scenario of chaos at the entrance of emergency health care services caused by the high demand of users with low complexity complaints that could be addressed in primary care, the use of ACCR even in those cases seems to be the most assertive conduct to provide humanized care in these Services.

Concerning care to users with non-complexity complaints by means of risk rating, we emphasize the importance of the scientific knowledge of the nursing staff to help identify the real needs in emergency services without losing focus on humanization as inherent in the care process. This is important because when nurses use their knowledge and specific abilities to perform their duties, they use intuition, scientificity and communication ${ }^{(17-18),}$ essential tools in the provision of a compassionate and effective care by the nursing staff.

Again, not all cases that arrive at EHS are urgencies/ emergencies. So, the provision of care should be organized in such a way that priority is not based on the order of arrival, but on the patient condition ${ }^{(7)}$. In this study, the item "Patients seen in order of urgency" (Chart 1, item 15) showed the third best result, indicating that this ACCR assumption has been adequately dealt with by the investigated emergency services.

Historically, patient care in public institutions has been largely based on order of arrival, without previous assessment of the patients ${ }^{(17-18)}$. This conduct is certainly worrying, for it results in delayed care and exposes patients to unnecessary risks and/or complications, preventing the possibility of early intervention and appropriate management of their pathological conditions ${ }^{(4,6)}$. In order to minimize this distortion and the ineffectiveness of the care system, it is urgent to implement a praxis to organize and guide care management at EHS, such as ACCR.

Given the results from this and other similar studies, it is possible to affirm that there is much work still to be done in the EHS. Therefore, further studies on this issue are needed to help managers, health professionals and users detect the main aspects of EHS that require inter- 
vention and improvement, so that ACCR is effectively implemented not only as a strategy for humanization of care, but also as a resource for efficient/effective health management.

\section{$\square$ CONCLUSIONS}

The nursing staff of the EHS investigated rated the result of the implementation of ACCR as "Precarious", particularly because of the difficulties faced in the referral of low-complexity patients to primary care, lack of periodical discussion/evaluation of the ACCR patient flow and the inadequate physical space to accommodate patients' companions.

Of the three dimensions assessed, Result obtained the maximum score, according to all the participants.

Based on these results, it can be seen that although ACCR has been designed and implemented under the scope of the PNH, aimed to the restructuring of the health care system, some items related to the scope of the structure and the process require essential improvements in the assessed EHS.

It is concluded that, despite the inherent difficulties faced by the Brazilian health care system, the nursing staff of the investigated services considered the ACCR proposal to be a positive step and implemented it. However, many aspects deserve better consideration to ensure full compliance of ACCR guidelines. Besides, the non reassessment of the flowchart should also be a matter of concern to the managers of these hospitals, as we may wonder whether ACCR is conducted in a rather mechanical way, without much thought.

We believe that the findings of the present study may contribute to the development of new processes of implementation and/or monitoring of ACCR, improving the quality of the care delivered by the nursing staff to users.

Regarding teaching, we stress the importance of the inclusion of these subjects in the curricula for health care courses as a strategy to raise awareness of the future professionals and promote changes in the workplace.

Regarding nursing, it plays a key role in the success of ACCR because of the nature of this profession. Therefore, information obtained in assessment studies, such as those presented here, may support the adoption of more assertive managerial actions in nursing, focused on the implementation and monitoring of ACCR in EHS.

Regarding a possible contribution to the scientific community, since the theme addressed here is still under development in the praxis of the EHS, this study provides valuable data for further investigations on the issue, as well as to a teaching of nursing based on compassionate and comprehensive care, with a sense of humanity.

Given the methodological limitation of this study, which is cross-sectional and allows only an instant/partial view of the investigated reality, we suggest that further studies using different designs are conducted, e.g. with a qualitative approach, or longitudinal studies, which contemplate other variables of the investigated phenomenon, such as time.

\section{REFERENCES}

1. Souza CC, Toledo AD, Tadeu LFR, Chianca TCM. Classificação de risco em pronto-socorro: concordância entre um protocolo institucional brasileiro e Manchester. Rev Latino-Am Enfermagem. 2011;19(1):1-8.

2. Ministério da Saúde (BR). Política nacional de atenção as urgências. Braślia (DF); 2006

3. Garlet ER, Lima MADS, Santos JLG, Marques GQ. Finalidade do trabalho em urgências e emergências. Rev Latino-Am Enfermagem. 2009:17(4):535-40.

4. Ministério da Saúde (BR), Secretaria Executiva. Núcleo Técnico da Pollitica Nacional de Humanização (Humaniza SUS). Política nacional de humanização: a humanização como eixo norteador das práticas de atenção e gestão em todas as instâncias do SUS. Brasilia (DF); 2004. Disponível em: http://bvsms.saude.gov. br/bvs/publicacoes/humanizasus_2004.pdf.

5. Hiestand B, Moseley M, MacWilliams B, Southwick J. The influence of emergency medical services transport on emergency severity index triage level for patients with abdominal pain. Acad Emerg Med. 2011;18(3):261-6.

6. Ministério da Saúde (BR), Secretaria de Atenção à Saúde. Acolhimento e classificação de risco nos serviç̧os de urgênncia. Brasilia (DF); 2009.

7. Santos AE. Humanização em serviços de emergência. In: Calil AM, Paranhos WY, organizadoras. 0 enfermeiro e as situações de emergência. São Paulo: Atheneu; 2010. p. 139-48.

8. Bittencourt RJ, Hortale VA. Intervenções para solucionar a superlotação nos serviços de emergência hospitalar: uma revisão sistemática. Cad Saúde Pública. 2009;25(7):1439-54.

9. Shiroma LMB, Pires DEP. Classificação de risco em emergência: um desafio para as/os enfermeiras/os. Enferm Foco. 2011;2(1):14-7.

10. Bellucci Júnior JA, Matsuda LM. Construção e validação de instrumento para avaliação do acolhimento com classificação de risco. Rev Bras Enferm. 2012;65(5):751-7.

11. Donabedian A. Criteria and standards for quality assessment and monitoring. QRB Qual Rev Bull. 1986;12(3):99-108.

12. Ministério da Saúde (BR). Conselho Nacional de Saúde. Resolução n 466, de 12 de dezembro de 2012. Diretrizes e normas regulamentadoras de pesquisas envolvendo seres humanos. Brasília (DF); 2012 [citado 2013 out 02]. Disponível em: http://conselho.saude.gov.br/resolucoes/2012/Res0466.pdf

13. Versa GLGS, Murassaki ACY, Inoue KC, Melo WA, Faller JW, Matsuda LM. Estresse ocupacional: avaliação de enfermeiros intensivistas que atuam no período noturno. Rev Gaúcha Enferm. 2012;33(2):78-85.

14. Silva LG, Matsuda LM. Um olhar para a qualidade no processo de atendimento em um serviço de urgência público. Cienc Cuid Saude 2012;11(Supl.):121-8. 
15. Bellucci Júnior JA, Matsuda LM. Implantação do acolhimento com classificação de risco e uso do fluxograma analisador. Texto Contexto-Enferm. 2012;21:217-25.

16. Dal Pai D, Lautert L. Sofrimento no trabalho de enfermagem: reflexos do "discurso vazio" no acolhimento com classificação de risco. Esc Anna Nery. 2011;15(3):524-30.
17. Cavalcante RB, Rates HF, Silva LTC, Mello RA, Dayrrel KMB. Acolhimento com classificação de risco: proposta de humanização nos serviços de urgência. Rev Enferm Cent 0 Min. 2012;2(3):428-37.

18. Acosta AM, Duro CLM, Lima MADS. Atividades do enfermeiro nos sistemas de triagem/classificação de risco nos serviços de urgência: revisão integrativa. Rev Gaúcha Enferm. 2012;33(4):181-90.

\section{Author's address:}

Gelena Lucinéia Gomes da Silva Versa

Rua Visconde do Rio Branco, 3511, Centro

85810-180 Cascavel - PR

E-mail: gelenaenfermagem@yahoo.com.br
Received: 07.03.2014

Approved: 08.08.2014 